\title{
Fingerprint: A Unique and Reliable Method for Identification
}

\author{
Palash Kumar Bose ${ }^{1}$, Mohammad Jubaidul Kabir ${ }^{2}$ \\ Received: September 12, 2016 Accepted: December 7, 2016 \\ doi: http://dx.doi.org/10.3329/jemc.v7i1.30748
}

\begin{abstract}
Fingerprints have been the gold standard for personal identification within the forensic community for more than one hundred years. It is still universal in spite of discovery of DNA fingerprint. The science of fingerprint identification has evolved over time from the early use of finger prints to mark business transactions in ancient Babylonia to their use today as core technology in biometric security devices and as scientific evidence in courts of law throughout the world. The science of fingerprints, dactylography or dermatoglyphics, had long been widely accepted, and well acclaimed and reputed as panacea for individualization, particularly in forensic investigations. Human fingerprints are detailed, unique, difficult to alter, and durable over the life of an individual, making them suitable as lifelong markers of human identity. Fingerprints can be readily used by police or other authorities to identify individuals who wish to conceal their identity, or to identify people who are incapacitated or deceased, as in the aftermath of a natural disaster.
\end{abstract}

Keywards: Fingerprint; Identification; AFIS

J Enam Med Col 2017; 7(1): 29-34

\section{Introduction}

Dactylography is a progressing science and a new method for recording, lifting and developing of prints under different field conditions appearing regularly. ${ }^{1} \mathrm{~A}$ fingerprint in its narrow sense is an impression left by the friction ridges of a human finger. ${ }^{2-5}$ The fingerprint system is based on the principle that the skin of the balls of the fingers and thumbs is covered with ridges and grooves; the pattern of which varies between individuals and makes absolute identification possible. ${ }^{6}$ It has served governments worldwide for over 100 years to provide accurate identification of criminals. ${ }^{7}$ In the world's crime records, no two identical fingerprint patterns have been reported. Even identical twins do not have identical fingerprints. ${ }^{8}$ The basis for this statement rests in human embryology and genetics, beginning during fetal development. ${ }^{9}$ In the case of criminals, impressions of all the digits of both hands are taken and preserved by the police for further identification. ${ }^{10}$

\section{Historical background of fingerprint}

Uses of fingerprints were found in ancient Babylonian,
Greek, Chinese and Roman civilization. Fingerprints are considered as the oldest friction ridge skin impressions found to date. But its deposition found in ancient civilizations was due to accidents or for specific intention like decoration or as symbol, is not clear. ${ }^{11} \mathrm{It}$ is thought that in this period, fingerprint was left in other ancient materials unintentionally by builders and left impressions in clay used to make bricks which is known as offline fingerprint acquisition. ${ }^{12,13}$

Fingerprints were found in Babylon in clay tabs, seals and pottery in which the deeds had been written in the second millennium BC. ${ }^{12,14-16}$ Law officials used to take the fingerprints of arrested people during the reign of King Hammurabi (1792-1750) BC in Babylon. ${ }^{17}$ These have also been seen on the walls of Egyptian tombs, Greek and Chinese potteries and also in bricks and tiles found in ancient Babylon and Rome. ${ }^{16}$

In the period of Chinese Dynasty, fingerprints as well as hand and footprints were collected and used as forensic evidence. By 650, the Chinese historian Kia Kung Yen and before $851 \mathrm{CE}$, Arab merchant Abu Zayd Hasan

1. Associate Professor, Department of Forensic Medicine, Enam Medical College, Savar, Dhaka

2. Associate Professor, Department of Forensic Medicine, Monno Medical College, Manikgonj

Correspondence Palash Kumar Bose, Email: palashbose223@hotmail.com 
witnessed fingerprints as a means of authentification. ${ }^{18,19}$ The famous Persian physician Rashed-al-Din Hamadani (1247-1318 AD) refers to the Chinese practice of identifying people via their fingerprints and commented that 'experience shows that no two individuals have fingerprints exactly alike'. ${ }^{20}$

Japan allowed its illiterate citizens to use fingerprints as the signature in divorce papers by 702. ${ }^{12,21}$ Although ancient people used fingerprints, probably they did not realize that fingerprints could uniquely identify individuals. ${ }^{22}$

Friction ridge skin was first described in details by Dr Nehemiah Grew in $1684 .{ }^{23}$ Gorarrd Bidloo published anatomy of the human body, which included details of the skin and the papillary ridges of the fingers. ${ }^{24}$ In 1687 Marcello Malphigi in his book described that the function, form and the structure of friction ridge of skin are unique. ${ }^{25} \mathrm{In}$ 1788, JCA Mayer, a German doctor, proved that the friction ridge of skin is unique. ${ }^{26,27}$ In $1823 \mathrm{Dr}$ Purkinge classified fingerprint patterns into nine categories and gave each a name. ${ }^{28}$ Later it paved the way of the Henry Classification System. ${ }^{27}$

In 1877 Sir William Harschel in India started to use fingerprints on contracts and deeds ${ }^{29}$ and registering prisoners. ${ }^{28}$ Later fingerprint bureau was established in Kolkata. Azizul Haque and Hem Chandra Bose were two Indian fingerprint experts who primarily developed a fingerprint classification system, named after their supervisor and it was known as Henry classification system. $^{30,31}$

First paper on fingerprint was published in the scientific Journal 'Nature' by Dr Henry Faulds in 1880 valuing of the friction ridge skin for individualization, especially its use as evidence. ${ }^{32}$ Sir Francis Galton then further worked on it and published details on fingerprint analysis and identification and showed that chance of false positive fingerprint was about 1 in 64 billion people. $^{33}$

Another leading fingerprint researcher was Juan Vucetich who was an employee in Central Police Department in Argentina. He began to experiment with fingerprints of criminals and introduced his own classification system. In 1892, he set up the world's first fingerprint bureau and applied fingerprint to identify criminals in court room $^{23}$ and thereby Argentina became the first country to rely solely on fingerprints as a method of individualization. ${ }^{34}$ Now-adays, it is used worldwide to recognize individual in any matter of disputes and questions in the premises of court.

\section{Classification of fingerprints}

A) Loops (about 60-70\%): (a) Radial (b) Ulnar

B) Whorls (about 25-35\%): (a) Concentric (b) Spiral (c) Double spiral (d) Almond shape

C) Arches (about 6-7\%): (a) Plain (b) Tented (c) Exceptional

D) Composite (about 1-2\%): (a) Central pocket loops (b) Lateral pocket loops (c) Twinned loops

E) Accidentals ${ }^{35-41}$

\section{Development of fingerprint in intrauterine life}

Fingerprints are formed by the development of primary and secondary ridges in the palms and fingers in intrauterine life at first four months of gestation which was described by Bonnevie in $1924^{42}$, Schaeuble in $1932^{43}$, Gould in $1948^{44}$, Hirsch in $1973^{45}$, Okajima in $1975^{46}$, Babler in $1991^{47}$ and Kucken in $2004^{48}$.

Cummins ${ }^{49}$ described that primary ridges develop first, followed by secondary ridge development or the occurrence of furrows between the papillary ridges. It is clearly documented and accepted that there is a link between the ridge pattern and anatomical structures called volar pads which are protuberances of tissue that begin to form on the tips of the fingers that form at about $7^{\text {th }}$ week at the fingertips, on the distal part of palm between the digits and thenar and hypothenar regions. Volar pads become less prominent after $10^{\text {th }}$ week of gestation and disappear in human embryos.

According to Kucken et $\mathrm{al}^{50}$, at $10^{\text {th }}$ to $11^{\text {th }}$ weeks, embryonic volar skin consists of layered epidermis on top of the more amorphous fibrous dermis where the basal layer of epidermis interfacing the dermis shows shallow projections and undulated to the dermis. These projections quickly become more prominent and form folds of the epidermis into the dermis which is termed as primary ridges. These primary ridges form the future fingerprint pattern which becomes established at $16^{\text {th }}$ week.

Hale $^{51}$ described that primary ridge formation ceases and secondary ridges begin to form as sweat gland anlagen to develop along the apices of the primary ridges at uniform intervals. At this time epidermal ridges first begin to appear 
on the volar surfaces. Around $24^{\text {th }}$ week of gestation, dermal papillae are reported to develop, characteristics of the definite dermal ridges are progressively formed.

\section{Fingerprint uniqueness in twins}

Fingerprint is unique due to its variations in twin babies. Twins are of dizygotic (fraternal twin) or monozygotic (identcal twin). ${ }^{52}$ The frequency of identical twins is about $0.4 \%$ across different populations. ${ }^{53}$ Fingerprints can be used to distinguish between twins.

Jain et $\mathrm{al}^{54}$ showed, by comparing 94 pairs of identical twins, that the verification system can be used to distinguish fingerprints of identical twins. By analyzing 66 pairs of twins, Han et al ${ }^{55}$ found that fingerprints can be used to identify identical twins with an insignificant error in the performance. Srihari et al ${ }^{56}$ analyzed the similarity between twin fingerprints of 298 pairs and found that the similarity between the fingerprints of twins is higher than that of two arbitrary fingers.

\section{Fingerprints in sex variations}

When an identification of a person is needed, sex of that person must be determined. From this point of view, sex-based differences in fingerprint pattern and the density of the finger ridges become relevant. Sex differences in fingerprint ridge density are highly individualistic and forms the basis for personal identification in forensic examination. Studies have showed that females have a significantly higher ridge density than males. Okajima ${ }^{57}$, Moore ${ }^{58}$, GutierrezRedomero et $\mathrm{al}^{59}$, Nayak et $\mathrm{al}^{60}$ and Krishan et $\mathrm{al}^{61}$ proved that epidermal ridges are finer and denser in females than males.

\section{Fingerprints found in scene of crime}

In general, the purpose of collecting fingerprints is to identify an individual. This person may be the suspect, a victim or a witness. There are three types of fingerprints which are found in scene of crime: latent, patent and plastic or impressed fingerprints. ${ }^{62}$

Latent fingerprint is invisible to the naked eye. This print is made of the sweat and oil on the skin's surface. Dusting, fumes or chemical agents help us to make latent print to be visible. Since fluorescent techniques are very sensitive, only the trace amounts of fluorescent powder is required when dusting for prints at a crime scene. It, therefore, leaves the scene much cleaner than when using black powder. ${ }^{63,64}$
Patent fingerprints can be made by blood, grease, ink or dirt. This type of fingerprint is easily visible to the human eye. Plastic fingerprints are three dimensional impressions and can be made by pressing fingers in fresh paint, wax, soap or tar. Like patent fingerprint, plastic fingerprint are easily seen by human eye and do not require additional processing for visibility purpose. $^{65,66}$

\section{Fingerprint database in the world}

Now, many countries in the world preserve fingerprint of the persons traveling and living in and around the country to manage a database in order to identify any persons when needed. Thus it is used to detect criminals to make the lives safe and comfortable from any terrorist activities. INTERPOL has a database containing more than 189000 fingerprint records (as of December 2013) ${ }^{67}$

The FBI has long been a leader in biometrics. In the United States, the FBI manages a fingerprint identification system and database called the Integrated Automated Fingerprint Identification System or IAFIS which currently holds the fingerprints and criminal records of over 51 million criminal record subjects and over 1.5 million civil (non-criminal) fingerprint records. ${ }^{68}$

\section{Fingerprint databases in Bangladesh}

Fingerprint is now widely used by different organizations in Bangladesh to secure the identity of a person, to detect criminals and thereby to improve law and order situation of the country by lowering criminal activities. Fingerprint database is mainly managed by Bangladesh Election Commission where persons above the age of 18 years are included as voters whose pictures, fingerprints and other information are kept in a central database. Bangladesh Election Commission now maintains information totally of about 9,19,80,531 persons including their fingerprints. Of them males are $4,61,35,965$ and females are 4,58,44,566 and the M:F ratio is almost 50:50\%. ${ }^{69}$

On the other hand, Bangladesh Telecommunication Regulatory Commission (BTRC) announced that more than 130 million of Bangladesh's 160 million people had mobile phone SIMs tiil August 2015. Now, BTRC has declared to register all SIM card holders by taking their fingerprints which is known as Biometric SIM registration and in future no SIM card will be sold without taking the fingerprint along with other information as needed previously. SIM cards must be 
registered along with fingerprint or otherwise discarded. ${ }^{70}$

Machine readable passports (MRP) are being issued by Bangladesh Government instead of handwriting passport which was issued in past. Total numbers of passports issued were more than 10 million by taking fingerprints of 10 fingers of hands along with all other documents. ${ }^{71}$ These all will maintain simultaneously the safety and security of the people of Bangladesh from any criminal acts committed by the criminals and quickly find out their past criminal records in police station and courts. These steps will also help to protect not only safety and security of Bangladesh but also will enhance regional and global peace and harmony.

Moreover, Rapid Action Battalion (RAB) has launched online database of 30,000 prisoners with 200 information including fingerprints and retinal scan to identify them easily in order to keep an eye on cunning criminals, especially militants who often commit crimes under different names in 68 districts across the country. ${ }^{72}$

\section{Fingerprint experts in Bangladesh}

Criminal Investigation Department (CID) is one of the ancient and specialized units of Bangladesh Police which deals with crime scene investigation that is one of most important functions of CID in detection of serious crimes. To carry out this procedure, CID has to depend on its valuable expert opinions. CID has its Forensic Division comprised of various subdivisions - Fingerprint Bureau, comprised of fingerprint experts, is one of them.

The Fingerprint Bureau compares the impression of fingerprints collected from the scene of crime with the fingerprints of the suspects as well as past convicts. The Bureau is to maintain fingerprint records too. Furthermore, after inclusion of new edition computer generated Automated Fingerprint Identification System (AFIS), the capability of criminal identification of Bangladesh Police has been increased tremendously. ${ }^{73}$

\section{Computer-generated fingerprint matching system}

The use of computer system for automatic reading, classification and coding of fingerprints is in much progress. It is based on light reflected from a fingerprint that can be measured and converted to digital data in order to classify and preserve for further comparative study.

The common framework of Fingerprint Identification System (FIS) is fingerprint matching in the last steps of
Automatic Fingerprint Identification System (AFIS). Fingerprint matching technique can be classified into three types correlation based matching, minutiae based matching and feature based matching. $4,74,75$

AFIS employees learned first to take a quality fingerprint in priority basis to maintain a good database. ${ }^{76}$ The major steps involved in this system include fingerprint acquisition, fingerprint segmentation, fingerprint image enhancement, feature extraction, minutiae matching and fingerprint classification. ${ }^{35}$

\section{Conclusion}

To save the society from the criminals and terrorists and to make the lives more comfortable, fingerprint can play a very important role. With advancement of technology and more sophisticated integration of this technique and its application will enhance more quick and accurate result even from partial print of fingers.

\section{References}

1. Vij Krishan. Identification. In: Textbook of forensic medicine $\&$ toxicology, $6^{\text {th }}$ edn. New Delhi: Reed Elsevier Pvt. Ltd., 2014: 46-89. ISBN-978-81-312-3785-4.

2. Ross A, Dass S, Jain AKA. Deformable model for fingerprint matching. Journal of Pattern Recognition 2005; 38(1): 95-103.

3. Yev AJ, Altunkaya RH. Neural network based biometric personal identification, Fronteirs in the convergence of bioscience and information technologies, Jeju island, Korea. Available at: www.sersc.org/FBIT2007/. Accessed December 2015.

4. Ji L, Yi Z. Fingerprint orientation field estimation using ridge projection. Journal of Pattern Recognition 2008; 41(1): 491-503.

5. Peer Reviewed Glossary of the Scientific Working Group on Friction Ridge Analysis, Study and Technology (SWGFAST) 2009, Version-2(PDF). Available at: www. swgfast.org/documents/glossary/090508_Glossary_ 2.0_Archived.pdf. Accessed November 2015.

6. Nandy A. Identification of an individual. In: Principle of forensic medicine including toxicology. Kolkata: Central Book Agency, 2014: 89-188. ISBN-978-81-7381-064-0.

7. The history of fingerprints. Available at: http:// www.brawleyonline.com/consult/history.htm. Accessed November 2015.

8. Parikh CK. Personal identification. In: Parikh's textbook of medical jurisprudence, forensic medicine and toxicology. $6^{\text {th }}$ edn. New Delhi: CBS Publishers \& Distributors PVT Ltd, 2014: 2.1-2.2. ISBN: 81-239-0675-7.

9. Shephard R. Identification of the living and the dead. In: Simpson's forensic medicine. $12^{\text {th }}$ edn. London: Hodder Arnold, 2003: 49-55. ISBN-0-340-76422-8. 
10. Fingerprints and human identification. Available at: www. bleaching-dental.com. Accessed November 2015.

11. Xiang-Xin Z, Chun Ge L. The historical application of hand prints in Chinese litigation. J Forensic Iden 1988; 38(6): $277-284$

12. Ashbaugh DR. History of friction ridge identification. In: An introduction to basic and advanced ridgeology: quantitativequalitative friction ridge analysis. Florida: CRC Press Boca Raton, 1999: 11-38. ISBN: 978-0-8493-7007-6

13. Maltoni D, Maio D, Jain AK, Prabhakar S. Fingerprint sensing. In: Handbook of fingerprint recognition. $2^{\text {nd }}$ edn. London: Springer-verlag Ltd., 2009: 57-95. ISBN-978-184882-253-5.

14. Berthold L. History of the finger-print system. Smithsonian Institution Annual Report 1912. Reprinted in: The Print, Newsletter of South California Association of Fingerprint Officers 2000; 16(2): 1-13.

15. Paul A. The study of ancient fingerprints. Journal of Ancient Fingerprints 2007; 1(1): 2-3.

16. Paul A, Eriksson SA. Fingerprints and archaeology 28. In: Studies in mediterranean archaeology series 1, 2. Goteborg, Sweden, 1980. ISBN-9185058998.

17. Jarus O. Code of Hammurabi: ancient Babylonian laws. Available at: www.livescience.com/.39393-code-of-hammurabi. html. Accessed December 2016.

18. Laufer B. History of the finger-print system. $1^{\text {st }}$ edn. Washington. Smithsonian Institution, 1912: 1-22.

19. Chavannes E. Les livres chinois avant l'invention du papier. (Chinese books before the invention of paper). Journal Asiatique 1905; 10(5): 5-75.

20. Simon A. Cole. Epilogue: Bodily Identities, In: Suspect Identities: a history of fingerprinting and criminal identification, paperback edn, Cambridge. Harvard University Press, 2002: 303-311.

21. Polson CJ. Finger prints and finger printing: an historical study. Journal of Criminal Law and Criminology 1951; 41(4): 495-517.

22. Harold C. Ancient finger prints in clay. The Scientific Monthly 1941; 52(5): 389-402.

23. Lambourne $G$. The fingerprint story. $1^{\text {st }}$ edn. London: Chambers, 1984: 1-208

24. Felsher IM. A quick look at dermatoglyphics. Ident News 1962; 12(7): 6-12

25. Barnes GJ. The history of fingerprint. Available at: http: //www.ncjrs.gov/pdffiles 1/nij/225321.pdf.Accessed November 2015.

26. Polson CJ. Fingerprint and fingerprinting: an historical study. Journal of Criminal Law and Criminology 1951; 41(5): 690-704.

27. Herchel WJ. The origin of fingerprinting. London: Oxford University Press, 1916: 7-41.
28. Galton F. Previous use of fingerprints. In: Finger Prints. New York: MacMillan \& Co., 1892; 22-27. Available at: http:// www.BiometricBits.htm. Accesed September 2016.

29. Fingerprint patterns. Available at: http://odec.ca/ projects/2004/fren4j0/public_html/fingerprint_patterns.htm). Online Digital Education. Connection. Accessed February 2016

30. Hirsch WJ. Morphological evidence concerning the problem of skin ridge formation. J Ment Defic Res 1973; 17: 58-72.

31. Tewari RK, Ravikumar KV. History and development of forensic science in India J Postgrad Med 2000; 46(4): 303-308.

32. Faulds H. On the skin-furrows of the hand. Nature 1880; 22: 605 .

33. Reid DL. Dr. Henry Faulds-Beith Commemorative Society. Journal of Forensic Identification 2003; 53(2): 15.

34. Beavan C. Chronology of fingerprints. In: Fingerprints - the origins of crime detection and the murder case that launched forensic science. $1^{\text {st }}$ edn. Newyork: Hyperion, 2001: XIV-XVI.

35.Uma SM, Chandra E. A review study on fingerprint classification algorithm used for fingerprint identification and recognition. IJCST 2012; 3(1): 739-745.

36. Adebisi S. Fingerprint Studies - the recent challenges and advancements: a literary view. The Internet Journal of Biological Anthropology 2008; 2(2): 1-9.

37. Henry ER .Classification and uses of fingerprints (part 1). London: George Rutledge and Sons Ltd., 1900: 3-9. Available at: https://archive.org/download/ classificationa0 1henrgoog/ classificationa01henrgoog.pdf. Accessed January 2016

38. Ehrlich EG. Review on the hands as a mirror of systemic disease. Philadelphia: Davis Company, 1963: 1-215. doi: 10.1002/art.1780080310.

39. Karu K, Jain AK. Fingerprint Classification. J Pattern Recognition 1996; 29(3): 389-404.

40. Reddy KSN, Murty OP. Identification. In: The essentials of forensic medicine and toxicology. $33^{\text {rd }}$ edn. New Delhi: Jaypee Brothers Medical Publishers Ltd., 2014: 57-101. ISBN: 978-93- 5152-557-8.

41. Kucken M, Alan CN. Fingerprint formation. Journal of Theoretical Biology 2005; 235: 71-83. doi: 10.1016/ j.jtbi.2004.12.020.

42. Bonnevie K. Studies on papillary patterns in human fingers. J of Genetics 1924; 15: 1-111.

43. Schaeuble J. Die Entstehung der primatenplanta unter mitberucksichtigung der palma teil I Morphol. Anthropol 1932; 37: 218-258.

44. Gould ES. A topographic study of the differentiation of the dermatoglyphics in the human embryo [Ph.D thesis]. New Orleans: Tulane University; 1948. 
45. Hirsch W. Morphological edidence concerning the problem of skin ridge formation. J Ment Deficiency Result 1973; 17(1): 58-72.

46. Okajima M. Development of dermal ridges in the fetus. J. Med. Genet. 1975; 12(3): 243-250.

47. Babler W. Embryologic development of epidermal ridges and their configurations. Birth defects original article series 1991; 27(2): 95-112

48. Kuecken M. On the formation of fingerprints [Ph.D. Thesis]. Arizona: University of Arizona; 2004.

49. Cummins H. The topographic history of the volar pads (walking pads; Tastballen) in the human embryo. Contributions to Embryology 1929; 113(20): 105-126.

50. Kuecken M, Newell A. A model for fingerprint formation. Europhysics Letters 2004; 68(1): 141-146.

51. Hale A, Morphogenesis of volar skin in the human fetus. Am. J. Anat. 1951; 91: 147-180.

52. Tao X, Chen X, Yang X, Tian J. Fingerprint recognition with identical twin fingerprints. Public Library of Sciences (PLoS) ONE 2012; 7(4): e35704.

53. Nature and frequency of genetic disease. In: Rimoin D, Pyeritz R, Korf B (eds). Emery and Rimoin's principles and practice of medical genetics. $6^{\text {th }}$ edn. London: Academic Press, 2013: 1025-1027.

54. Jain AK, Prabhakar S, Pankanti S. On the similarity of identical twin fingerprints. Pattern Recognition 2002; 35(11): 2653-2663.

55. Han Y, Ryu C, Moon J, Kim H, Choi H. A study on evaluating the uniqueness of fingerprints using statistical analysis. Information Security and Cryptology - ICISC 2004; 3506: 467-477.

56. Srihari SN, Srinivasan H, Fang G. Discriminability of fingerprints of twins. Journal of Forensic Identification 2008; 58(1): 109-127.

57. Okajima M. Frequency of fork in epidermal ridge minutiae in fingerprint. Am J Phy Anthropol 1970; 32(1): 41-48.

58. Moore RT. Automatic fingerprint identification systems. In: Lee HC, Gaensslen RE (eds), Advances in fingerprint technology. $2^{\text {nd }}$ edn. Florida: CRC Press, 1994.

59. Gutierrez-Redomero E, Alonso C, Romero E, Galera V. Variability of fingerprint ridge density in a sample of Spanish Caucasians and its application to sex determination. Forensic Sci Int 2008; 180(1): 17-22.

60. Nayak VC, Rastogi P, Kanchan T, Lobo SW, Yoganarsinhma $\mathrm{K}$, Nayak $\mathrm{S}$ et al. Sex differences from fingerprints ridge density in the Indian Population. $\mathrm{J}$ of Forensic and Legal Medicine 2010; 17(3): 84-86.

61. Krishan K, Ghosh A, Kanchan T, Ngangom C, Sen J. Sex differences in fingerprint ridge density-causes and further observation. J of Forensic and Leg Med 2010; 17(3): 172-173.

62. Yoon S, Feng J, Jain AK. Altered fingerprints: analysis and detection. IEEE Transactions on Pattern Analysis and Machine Intelligence 2012; 34(3): 451-464.
63. Yoon S, Jain AK. Longitudinal study of fingerprint recognition. MSU Technical Report, 2014, MSU-CSE-14-3. Available at: http://www.cse.msu.edu/rgroups/biometrics/ Publications/Fingerprint/YoonJain_LongitudinalStudyofFing erprint_MSUTechReportMSU-CSE-14-3.pdf.

64. Cao K, Jain AK. Learning fingerprint reconstruction: from minutiae to image. IEEE Transactions on Information Forensics and Security 2015; 10 (10): 104-117.

65. Arora SS, Liu EK, Cao K, Jain AK. Latent fingerprint matching: performance gain via feedback from exemplar prints. IEEE Transactions on Pattern Analysis and Machine Intelligence 2014; 36(12): 2452-2465.

66. Zhao Q, Feng J, Jain AK. Latent fingerprint matching: utility of Level 3 features 2010, MSU Technical Report. MSUCSE-10-14. Available at: http://biometrics.cse.msu.edu/ Publications/Fingerprint/ZhaoFengJain_LatentFPMatching _UtilityLevel3Features_TIFS10.pdf.

67. International Criminal Police Organization. INTERPOL's fingerprints Database Oct 2015. Available at: http://www.interpol.int/INTERPOL-expertise/Databases. Accessed December 2015.

68. Federal Bureau of Investigation. Integrated Automated Fingerprint Identification System (IAFIS), January 2016. Available at: https://en.wikipedia.org/.../Integrated_Autom. Accessed February 2016.

69. Election Commission, Bangladesh. Voter registration/ Registration Form/News Updates on Summary of the updated voter list published on 01/02/15. Available at: http:// www.ec.org.bd/NewsFilesEng/250.pdf. Accessed December 2015.

70. Senior correspondent. Bangladesh starts trial for biometric SIM registration. bdnews24.com.published on 21/10/2015. Available at: bdnews24.com/.../2015/.../bangladesh-starts-t. Accessed November 2015.

71. Department of Immigration and Passport, Bangladesh/News. Available at: www.dip.gov.bd. Accessed December 2015.

72. Khan MJ, RAB's prison database launched. Dhaka Tribune. Published on $8^{\text {th }}$ Feb, 2016. Available at: archive. dhakatribune.com/bangladesh/2016/feb/08/rabs-prisondatabase-launched. Accessed February 2016.

73. Bangladesh Police. Criminal Investigation Department (CID). Available at: www.police.gov.bd/unitscontent. Accessed December 2015.

74. Jie Y, Fang Y, Renjie Z, Qifa S. Fingerprint minutiae matching algorithm for real time system. Pattern Recognition 2006; 39(6): 143-146.

75. Liu F, Zhao Q, Zhang DA. Hierarchical fingerprint matching approach. Pattern Recognition 2011; 44(16): 4-13.

76. King County Regional Automated Fingerprint Identification System: Future of AFIS including AFIS initiatives 2007-2012. Available at: www.kingcounty.gov/.../ AFIS/.../ AFISSectio... Accessed January 2016. 